16. Kirilov, A, and P. Todorova. 2004. Development of forage areas and forage resources in Bulgaria during the period of transition. Land use systems in grassland dominated regions, Grassland Science in Europe. 9:855-857 (in English).

17. http://www.mzh.government.bg (in Bulgarian).

18. Najdenova, J., and D. Pavlov. 2001. Spektroskopija v blizkata infrachervena oblast (NIRS) za ocenka hranitelnata stojnost na furazh ot ezhova glavica (Dactylis glomerata L.) prez vegetacijata i torene s azot i sjara. II-ra Nacionalna konferencija „Postizhenija i perspektivi na vodnija rezhim i mineralnoto hranene na rastenijata $v$ B'lgarija”, Sbornik, BAN, Institut po fiziologija na rastenijata, Sofija, 2:60-63 (in Bulgarian).

19. Najdenova, J., and D. Pavlov. 2005. Kalibracionni modeli pri otrazhatelna spektroskopija v blizkata infrachervena oblast (NIRS) za predvizhdane hranitelnata stojnost na furazh ot zhitni i bobovi trevi. Zhivotnovъdni nauki, 4:24-29 (in Bulgarian).

20. Naydenova, Y., D. Pavlov, A. Katova and P. Day. 2003. Estimation of chemical composition and digestibility of perennial grasses by regression equations. Grassland Science in Europe, Optimal Forage Systems for Animal production and Environment, EGF-Int. Occ. Sym. Pleven, Bulgaria, 8:211-214 (in English).

21. Naydenova, Y., A. Kyuchukova, D. Pavlov. 2013. Plant cell walls fiber components analysis and digestibility of birdsfoot trefoil (Lotus corniculatus L.) in the vegetation. Agricultural Science and Technology, International Journal Published by Faculty of Agriculture. Trakia University, Stara Zagora, Bulgaria, 5(2):164-167 (in English).

22. Naydenova, Y., 2012. Forage quality analysis and evaluation of perennial grasses in the vegetation. Field Crop Studies, Dobroudja Agricultural Institute. General Toshevo, Bulgaria, VIII(1):111-128 (in English).

23. Naydenova, Y. 2014. Forage quality analysis of perennial grass and legumes species in pure stands and mixtures. Journal of Animal Science. Sofia, 18(1-2):176-183 (in English).

УДК 636.2.034.061.082

\title{
ЛІНІЙНА КЛАСИФІКАЦІЯ КОРІВ-ПЕРВІСТОК ЗА ЕКСТЕР'СРОМ ТА ЇЇ ЗВ'ЯЗОК З МОЛОЧНОЮ ПРОДУКТИВНІСТЮ
}

\section{Г. Д. ІЛЯШЕНКО}

Кіровоградська державна сільськогосподарська дослідна станиія НААН (Созонівка, Украӥна) kirovogradgalina@ukr.net

Встановлено, щзо між рівнем надоїв за враховані першу і третю лактаиії та величиною показників оцінки будови тіла за 100-бальною системою існує достовірний додатній зв'язок. Збільшення оцінки за краший розвиток ознак, щчо характеризують будову тіла та якість вим'я, призводить до зростання надоїв корів як у першу, так $і$ в повновікову лактації. Результати градації підконтрольного поголів'я на класи згідно з міжнародною класифікаційною шкалою переконливо свідчать, щу рівень молочної продуктивності корів досліджуваних порід тотожний величині балів, отриманих за екстер'єрний тип.

Виявлений характер успадкування свідчть про можливість ведення селекиії в зазначеному напрямку і ефективного використання оцінених за потомством бугаӥв-поліпшувачів за ознаками екстер'єру.

Ключові слова: стадо, лінійна оцінка, будова тіла, молочна продуктивність, екстер'єрний тип, розвиток, сила впливу

Розведення і генетика тварин. 2018. Вип. 55 


\section{LINEAR CLASSIFICATION OF THE FIRST-CALF COWS BY THE EXTERIOR AND ITS CONNECTION WITH DAIRY PRODUCTIVITY}

\section{G. D. Ilyashenko}

Kirovograd State Agricultural Experimental Station of NAAS (Sozonivka, Ukraine)

It was established that between the level of milk yield for the first and the third lactations and the level of the body structure estimation indicators according to the 100-point system there was a reliable positive relationship. An increase in the evaluation for better development of the indicators that characterize the body structure and the quality of udder leads to an increase in the milk yield of cows in both the first and in full-grown lactations. The results of the gradation of the controlled livestock into classes according to the international classification scale persuasively indicate that the level of milk productivity of the cows of the studied breeds is identical with the quantity of the points obtained for the exterior type.

The revealed character of inheritance proves the possibility of conducting breeding in indicated direction and the effective use of progeny-tested bulls-improvers by the indicators of exterior.

Keywords: herd, linear estimation, body structure, milk productivity, exterior type, development, force of influence

\section{ЛИНЕЙНАЯ КЛАССИФИКАЦИЯ ПЕРВОТЕЛОК ПО ЭКСТЕРЬЕРУ И ЕЕ СВЯЗЬ С МОЛОЧНОЙ ПРОДУКТИВНОСТЬЮ}

\section{Г. Д. Иляшенко}

Кировоградская государственная сельскохозяйственная експерементальная станиия НААН (Созоновка, Украина)

Установлено, что между уровнем надоев за учтенные первую и третью лактации и величиной показателей оченки телосложения коров по 100-бальной системе, существует достоверная положительная связь. Увеличение оченки за лучшее развитие признаков, которые характеризуют телосложение и качество вымени приводит к росту надоев коров как в первую, так и в полновозрастную лактации. Результаты градации подконтрольного поголовья на классы согласно международной классификачионной шкале убедительно свидетельствуют, что уровень молочной продуктивности коров исследуемых пород тождественен величине баллов, полученных за экстерьерный тип.

Установленный характер наследования удостоверяет возможность ведения селекиии в этом направлении и эффективного использования, оцененных за потомством быков-улучшателей по признакам.

Ключевые слова: стадо, линейная оценка, телосложение, молочная продуктивность, экстерьерный тип, развитие, сила влияния

Вступ. У селекційно-племінній роботі з великою рогатою худобою чільне місце займає оцінка і добір тварин за зовнішніми формами і пропорціями будови тіла. Це зумовлено встановленим у практичній селекції та багатьох дослідженнях зв'язком між особливостями екстер'єру тварин та їхніми господарськи корисними ознаками, міцністю, технологічністю і тривалістю продуктивного використання [7].

При виведенні та подальшому удосконаленню української червоної та чорно-рябої молочних порід були закладені вимоги до екстер'єру тварин, який, згідно з вимогами сучасних технологій виробництва молока, має бути максимально наближеним до бажаного молочного типу, пристосованим до умов зовнішнього середовища, характеризуватися добрим здоров'я та міцною будовою тіла [7].

Більшість вчених зазначають, що високопродуктивні корови, як правило, масивні, об'ємні, добре розвинені тварини, мають виражений тип, розвинену молочну залозу і на 10$15 \%$ вищу за середні показники стада живу масу $[5,6]$. Також встановлений характер успадкування ознак екстер'єру від 10,0 до 29\% за українською червоною молочною породою та від 15 до 42,5\% за українською чорно-рябою молочною породою, засвідчує про можливість ведення селекції в зазначеному напрямку [2]. 
Істотні селекційні досягнення в галузі молочного скотарства багатьох країн світу значною мірою завдячують використанню в селекційному процесі методики лінійної класифікації екстер'єрного типу тварин. Використання методики лінійної класифікації при оцінці корів молочних порід за повідомленнями П. А. Сарапкина, В. Ф Зубриянова, И. М Морозова, П. А. Степанова, В. А Примак, Л. М. Хмельничого та інших вчених (цит. за [8]), дозволило підвищити об’єктивність оцінки бугаїв-плідників за типом їх дочок та на основі даних лінійної класифікації провести добір кращих за екстер'єром корів для подальшої селекції. Актуальність досліджень особливостей екстер'єру корів молочних порід та впровадження окомірної оцінки на практиці підтверджується новою редакцією закону України «Про племінну справу в тваринництві», який зобов'язує використовувати лінійну класифікацію як складовий елемент в комплексній оцінці племінної цінності тварин.

Метою досліджень стало вивчення зв'язку екстер'єру корів українських червоної і чорно-рябої молочних порід з їх молочною продуктивністю в умовах Центрального регіону України.

Матеріали та методи досліджень. Дослідження були проведені на коровах-первістках української червоної молочної породи (УЧМ, $\mathrm{n}=82)$ та української чорно-рябої молочної породи (УЧРМ, n=39), дослідного господарства “Елітне” Кіровоградської державної сільськогосподарської дослідної станції НААН, що отелились впродовж 2011-2016 роки.

Оцінка екстер'єрного типу проводилася за методикою лінійної класифікації [3] згідно останніх рекомендацій ICAR [4] у віці 2-4 місяців після отелення, з лінійним описом 18 статей екстер'єру і 100-бальною системою класифікації з урахуванням чотирьох комплексів селекційних ознак, які характеризують: вираженість молочного типу, розвиток тулуба, стан кінцівок і морфологічні якості вим'я. Однофакторним дисперсійним аналізом визначали рівень впливу генетичного чинника походження за батьком на показники екстер'єру корів-первісток. Обчислення здійснювали методами математичної статистики засобами програмного пакету “STATISTICA-6.1”[1]. Розрахунок економічної ефективності розведення тварин проводили шляхом обчислення вартості додатково виробленого молока (Е) за формулою, пропонованою Н. В. Пономаренко [4]:

$$
E=Ц \times(P \times \Pi) / 100 \times Л \times K,
$$

де $Ц$ - середня ціна реалізації 1 ц молока, грн.; $P$ - середня продуктивність корів, ц за рік; П- відносна прибавка продуктивності у корів (вища оцінка за екстер'єр), \%; Л- постійний коефіцієнт $(0,75)$, пов'язаний з витратами на виробництво додаткової кількості молока; $K-$ кількість корів. Коректність обчислень розрахункового економічного ефекту досягалась також використанням даних ДКС України про фактичну середню ціну реалізації 1 ц молока саме у Кіровоградській області станом на кінець 2017 року.

Результати досліджень. Об'єктивне уявлення про розвиток важливих статей екстер'єру корови відокремлено від групових, які мають певну селекційну цінність, дозволяє зробити описова система лінійної класифікації. При цьому, за рекомендацією ICAR, кожна лінійна ознака описує унікальну стать корови, яка відокремлена від інших ознак.

Нами проведено оцінку екстер'єрного типу корів-первісток українських червоної і чорно-рябої молочних порід дослідного господарства "Елітне” КДСГДС НААН за методикою лінійної класифікації, яка вказує на певний ступінь міжпорідної диференціації за основними ознаками. Загальна оцінка будови тіла за досліджуваними первістками коливалась від 80,5 за УЧМ до 81,6 балів за УЧРМ, що відповідає «добре 3 плюсом». Різниця становить 1,1 1 1,58 балів $\left(\mathrm{t}_{\mathrm{d}}=0,76\right)$ на користь первісток української чорно-рябої молочної породи. Разом 3 тим, за розвитком тулуба, станом кінцівок та морфологічними ознаками вим'я останні також переважали аналогів української червоної молочної породи на $1,7 \pm 1,58$ бала $\left(\mathrm{t}_{\mathrm{d}}=1,08\right), 1,8 \pm 2,18$ $\left(\mathrm{t}_{\mathrm{d}}=0,83\right)$ i $2,1 \pm 1,13$ бала $\left(\mathrm{t}_{\mathrm{d}}=1,86\right)$. Проте, кількість балів за молочний тип була вищою у тварин УЧМ на $1,1 \pm 0,92$ при $t_{d}=0,83$. 3 огляду на те, що до аналізу було залучено невелика чисельність тварин, рівень вірогідності у всіх випадках виявився низьким.

Показники комплексів ознак екстер'єру (табл. 1) за роками оцінки показали, що коровипервістки УЧМ, які отелилися у 2011 році, поступались за молочним типом ровесницям, що 
отелились у 2016 році, на 2,2 бала $\left(\mathrm{t}_{\mathrm{d}}=1,55\right)$, за розвитком тулуба - на $3\left(\mathrm{t}_{\mathrm{d}}=2,13, \mathrm{P}<0,05\right)$, за станом кінцівок - на $1,8\left(\mathrm{t}_{\mathrm{d}}=0,80\right)$, за морфологічними ознаками вим'я - на 2,0 бала $\left(\mathrm{t}_{\mathrm{d}}=0,97\right)$. За УЧРМ відповідна різниця становила 2,9 бала $\left(\mathrm{t}_{\mathrm{d}}=2,57\right), 2\left(\mathrm{t}_{\mathrm{d}}=1,05\right), 1,3\left(\mathrm{t}_{\mathrm{d}}=1,88\right)$ та 1,7 бали $\left(\mathrm{t}_{\mathrm{d}}=1,64\right)$.

1. Результати лінійної класифікації корів-первісток за роками отелення (за 100-бальною системою)

\begin{tabular}{|l|c|c|c|}
\hline \multirow{2}{*}{ Ознака екстер'єру } & \multicolumn{2}{|c|}{ Група корів за роками оцінки: } \\
\cline { 2 - 4 } & 2011 & 2015 & 2016 \\
\cline { 2 - 4 } & Х \pm S.E. & X \pm S.E. & x \pm S.E. \\
\hline \multicolumn{3}{|c|}{ Українська червона молочна порода } \\
\hline Оцінено тварин & 20 & 26 & 36 \\
\hline Ознаки, що характеризують: молочний тип & $80,6 \pm 1,25$ & $81,6 \pm 0,99$ & $82,8 \pm 1,02$ \\
\hline тулуб & $79,9 \pm 0,11$ & $81,2 \pm 0,43$ & $82,9 \pm 1,41$ \\
\hline кінцівки & $78,7 \pm 1,63$ & $79,5 \pm 1,05$ & $80,5 \pm 1,57$ \\
\hline вим'я & $79,8 \pm 1,06$ & $80,5 \pm 0,93$ & $81,8 \pm 1,77$ \\
\hline Загальна оцінка & $79,8 \pm 2,68$ & $80,7 \pm 0,72$ & $82,0 \pm 1,40$ \\
\hline Українська чорно-ряба молочна порода & 7 \\
\hline Оцінено тварин & 8 & $80,8 \pm 1,04$ & $82,3 \pm 0,88$ \\
\hline Ознаки, що характеризують: молочний тип & $79,4 \pm 0,72$ & $81,8 \pm 0,98$ & $83,0 \pm 1,32$ \\
\hline тулуб & $81,0 \pm 1,39$ & $81,0 \pm 1,61$ & $81,5 \pm 1,58$ \\
\hline кінцівки & $80,2 \pm 1,03$ & $81,5 \pm 1,02$ & $82,5 \pm 1,11$ \\
\hline вим'я & $80,8 \pm 1,21$ & $81,2 \pm 1,12$ & $82,6 \pm 0,99$ \\
\hline
\end{tabular}

Отже, за аналізований період екстер'єр корів-первісток зазнав змін у бік покращення в обох досліджуваних стадах. Загальна оцінка будови тіла корів української червоної молочної породи становила у 2016 році 82,0 бала (проти 79,8 у 2011 році), української чорно-рябої молочної породи - відповідно 82,6 проти 80,8 бала.

У сучасній практичній селекції великої рогатої худоби молочного напрямку продуктивності в процесі оцінки екстер'єру тварин мають цінність ті статі, які безпосередньо або у комплексі впливають на величину продуктивності тварин.

За результатами наших досліджень встановлено, що між рівнем надоїв за враховані першу і третю лактації та величиною показників оцінки за 100-бальною системою існує достовірний додатній зв'язок. Збільшення оцінки за кращий розвиток ознак, що характеризують будову тіла (висота в крижах, глибина тулуба, кутастість, ширина заду, постава задніх кінцівок та стан ратиць) та якість вим'я (прикріплення передньої та висота задньої частини вим'я, розвиток центральної зв'язки), призводить до зростання надоїв корів як у першу, так і в повновікову лактації.

Для вивчення впливу оцінки за екстер'єрний тип на молочну продуктивність проведена градація підконтрольного поголів'я на класи згідно з міжнародною класифікаційною шкалою (табл. 2).

Результати розподілу переконливо свідчать, що рівень молочної продуктивності корів досліджуваних порід тотожний величині балів, отриманих за екстер'єрний тип. Так, корови-первістки української червоної молочної породи, які мали за будову тіла 85-88 балів за надоєм молока, достовірно переважали аналогів з оцінкою 80-84 на $799 \pm 296$ кг $\left(\mathrm{t}_{\mathrm{d}}=2,70\right), 3$ 75-79на $1719 \pm 491,4$ кг $\left(t_{d}=3,50\right)$, з 70-74 - на $2298 \pm 516,2$ кг $\left(t_{d}=4,45\right)$. За українською чорнорябою молочною породою - відповідно на $888 \pm 400,1$ кг $\left(\mathrm{t}_{\mathrm{d}}=2,22\right), 1908 \pm 595,9$ кг $\left(\mathrm{t}_{\mathrm{d}}=3,20\right)$, $2311 \pm 544,1$ кг $\left(\mathrm{t}_{\mathrm{d}}=4,25\right)$. За рівнем надою за третю лактацію корови, які мали вищу оцінку за екстер'єр, також перевищували аналогів з нижчими показниками $(\mathrm{P}<0,01)$.

Вплив генетичного чинника походження за батьком на екстер'єр корів української червоної молочної породи був порівняно невисокий, проте достовірний, сила впливу коливалась від $12 \%$ до $34 \%$. Сила впливу походження за батьком на показники екстер'єру тварин української чорно-рябої молочної породи коливалася від 13 до 37\%. Однак, за рахунок того, що до 
аналізу було залучено невелика чисельність тварин, рівень вірогідності у всіх випадках виявився низьким.

2. Надій корів-первісток, залежно від рівня оцінки за екстер'срний тип

\begin{tabular}{|c|c|c|c|c|c|}
\hline \multirow{3}{*}{$\begin{array}{c}\text { Загальна оцінка, } \\
\text { балів }\end{array}$} & \multirow{3}{*}{ Клас } & \multicolumn{4}{|c|}{ Надій молока за 305 днів, кг } \\
\hline & & \multicolumn{2}{|c|}{ I лактація } & \multicolumn{2}{|c|}{ III лактація } \\
\hline & & $\mathrm{n}$ & $\mathrm{x} \pm$ S.E. & $\mathrm{n}$ & $x \pm$ S.E. \\
\hline \multicolumn{6}{|c|}{ Українська червона молочна порода } \\
\hline $85-88$ & дуже добре & 15 & $7411 \pm 271,2$ & 14 & $8214 \pm 199,8$ \\
\hline $80-84$ & добре з плюсом & 108 & $6612 \pm 118,7$ & 113 & $7076 \pm 126,5$ \\
\hline $75-79$ & добре & 14 & $5692 \pm 409,8$ & 8 & $6056 \pm 498,2$ \\
\hline 70-74 & задовільно & 10 & $5113 \pm 439,2$ & 10 & $5727 \pm 473,1$ \\
\hline \multicolumn{2}{|c|}{ Надій усіх оцінених корів } & 147 & $6447 \pm 104,2$ & 145 & $6985 \pm 138,5$ \\
\hline \multicolumn{6}{|c|}{ Українська чорно-ряба молочна порода } \\
\hline $85-88$ & дуже добре & 8 & $8012 \pm 321,2$ & 10 & $8710 \pm 199,8$ \\
\hline $80-84$ & добре з плюсом & 24 & $7124 \pm 238,5$ & 20 & $7501 \pm 126,5$ \\
\hline $75-79$ & добре & 8 & $6104 \pm 501,9$ & 8 & $6445 \pm 492,2$ \\
\hline $70-74$ & задовільно & 10 & $5701 \pm 439,2$ & 8 & $6111 \pm 493,9$ \\
\hline \multicolumn{2}{|c|}{ Надій усіх оцінених корів } & 50 & $6811 \pm 154,2$ & 46 & $7205 \pm 218,5$ \\
\hline
\end{tabular}

Для визначення економічної ефективності застосування методики лінійної класифікації первісток за екстер'єром у піддослідному стаді для раннього прогнозуючого їх добору проведена градація поголів’я на класи згідно з міжнародною класифікаційною шкалою.

Результати розподілу свідчать, що надій висококласних тварин УЧМ перевищує такий з низькою оцінкою на 2298 кг, за УЧРМ - на 2311 кг.

У середніх реалізаційних цінах по Кіровоградській області станом 2017 року (678,29 грн. за ц, без ПДВ) вартість додатково одержаного молока на одну корову української червоної молочної породи становить 22,98 ц 678,29 грн. / ц = 15587,1 грн., української чорно-рябої молочної породи $-21,33$ ц × 678,29 грн. / ц = 14467,9 грн.

Для вироблення додаткової продукції буде понесено додаткові витрати на корми, заробітну плату, амортизацію обладнання і приміщень тощо. Тому вартість додатково виробленого молока (Е) обчислюється множенням селекційного ефекту за рік на постійний коефіцієнт $(Л=0,75)$, що пов'язаний з витратами на виробництво додаткової кількості молока.

Таким чином, розрахунковий економічний ефект за УЧМ становитиме $\mathrm{E}=15587,1 * 0,75=11690,3$ грн., за УЧРМ $-\mathrm{E}=14467,9 * 0,75=10850,9$ грн. на одну голову.

Висновки. 1. Застосування методики лінійної класифікації дозволило об'єктивно визначити особливості та мінливість екстер'єрних ознак корів. Виявлений характер успадкування засвідчує про можливість ведення селекції в зазначеному напрямку і ефективного використання оцінених за потомством бугаїв-поліпшувачів за ознаками екстер'єру.

2. Практичне використання в господарствах методики лінійної класифікації корів-первісток за екстер'єром забезпечує економічний ефект від 10850,9 до 11690,3 грн. на голову.

\section{БІБЛІОГРАФІЯ}

1. Боровиков, В. STATISTICA : искусство анализа данных на компьютере. Для профессионалов / В. Боровиков. - СПб. : Питер, 2001. - 656 с.

2. Іляшенко, Г. Д. Оцінка екстер'єру корів-первісток молочних порід / Г. Д. Іляшенко // Наука Освіта. Практика : матеріали наук.-практ. конф. присвяч. 20-річчю факультету екології і права ЖНАУ, 12.10.2017 р. - Житомир : Укрекобіокон, 2017. - С. 165-167.

3. Методика лінійної класифікації корів молочних і молочно-м'ясних порід за типом / Л. М. Хмельничий, В. І. Ладика, Ю. П. Полупан, А. М. Салогуб. - Суми : Мрія-1, 2008. - 28 с.

4. Пономаренко, Н. В. Методические указания по определению экономической эффективности использования результатов научно-исследовательских работ / Н. В. Пономаренко. Элгава, 1981. - 43 с. 
5. Реєстрація ICAR : довідник / В. І. Ладика, Л. М. Хмельничий, В. П. Буркат, С. Ю. Рубан. - Суми : Сумський національний аграрний університет, 2010. - 457 с.

6 . Екстер'єр молочних корів: перспективи оцінки і селекції / Й. 3. Сірацький, Я. Н. Данилків, О.М. Данилків, С. І. Федорович, В. В. Меркушин, Ю. Ф. Мельник, О. П. Чуприна, В. О. Кадиш, О. І. Любинський ; за ред. Й. 3. Сірацького, Є. І. Федорович. - К. : Науковий світ, 2001. - $146 \mathrm{c}$.

7 . Федорович, Є. І. Селекційні та біологічні особливості високопродуктивних корів чорнорябої породи в західному регіоні / С. І. Федорович, Й. 3. Сірацький // Вісник аграрної науки. К. - 2003. - № 3. - C. 35-39.

8 . Хмельничий, Л. М. Оцінка екстер'єру тварин в системі селекції молочної худоби : монографія / Л. М. Хмельничий. - Суми : Мрія-1, 2007. - 260 с.

9 . Хмельничий, Л. М. Оцінка екстер'єру корів-первісток сумського типу української чорно-рябої молочної породи / Л. М. Хмельничий // Вісник СНАУ. Серія «Тв-во». - 2008. Вип. 10 (15). - С. 127-131.

\section{REFERENCES}

1. Borovikov, V. 2001. STATISTICA : Isskustvo analiza dannykh na komp'yutere: dlya professionalov - STATISTICS : Art of computer data analysis: for professionals. S.-Peterburg, Piter, 656 (in Russian).

2. Ilyashenko, H. D. 2017. Otsinka ekster"yeru koriv-pervistok molochnykh porid. - Estimation of the exterior of first-calf cows of dairy breeds. «Nauka Osvita. Praktyka». Materialy naukovopraktychnoyi konferentsiyi, prysvyachenoyi 20-richchyu fakul'tetu ekolohiyi i prava ZhNAU. Zhytomyr: Vyd-vo ETs «Ukrekobiokon». - Zhytomyr: Publ. house of the EC "Ukrekobiokon". 165167 (in Ukrainian).

3. Khmelnychyi, L. M., V. I. Ladyka, Yu. P. Polupan, and A. M. Salohub. 2008. Metodyka liniinoi klasyfikatsii koriv molochnykh i molochno-miasnykh porid za typom - Method of linear classification of cows of dairy and dairy-meat breeds by type. Sumy : VVP "Mriia-1", 28 (in Ukrainian).

4. Ponomarenko, N. V. 1981. Metodicheskie ukazaniya po opredeleniyu ehkonomicheskoj ehffektivnosti ispol'zovaniya rezul'tatov nauchno-issledovatel'skih rabot - Methodological guidelines for determining the economic efficiency of using research results. Elgava, 43 (in Russian).

5. Ladyka, V. I., L. M. Khmel'nychyy, V. P. Burkat, and S. Yu. Ruban. 2010. Reyestratsiya ICAR. Dovidnyk - Registration ICAR. Reference book. Sumy : Sums'kyy Natsional'nyy Ahrarnyy Universytet, 457 (in Ukrainian).

6. Syrartzky, Y. Z., Ya. N. Danilkiv, O. M. Danilkov, Ye. I. Fedorovich, V. V. Merkushin, Yu. F. Melnyk, O. P. Chuprina, V. O. Kadysh, and O. I. Lubinsky. 2001. Ekster"yer molochnykh koriv : perspektyvy otsinky i selektsiyi. - Exterior of dairy cows : prospects for evaluation and selection. K., Naukovyy svit. 146 (in Ukrainian).

7. Fedorovych, Ye. I. and Y.Z. Sirats'kyy. 2003. Selektsiyni ta biolohichni osoblyvosti vysokoproduktyvnykh koriv chorno-ryaboyi porody v zakhidnomu rehioni - Selection and biological features of high-yielding black-and-white breed cows in the western region. Visnyk ahrarnoi nauky - Bulletin of Agrarian Science, 3: 35-39 (in Ukrainian).

8. Khmel'nychyy, L. M. 2007. Otsinka ekster"yeru tvaryn v systemi selektsiyi molochnoyi khudoby: monohrafiya. - Estimation of exteriors of animals in the system of selection of dairy cattle: monograph. Sumy : VVP "Mriya-1", 260 (in Ukrainian).

9. Khmel'nychyy, L. M. 2008. Otsinka ekster"yeru koriv-pervistok sums'koho typu ukrayins'koyi chorno-ryaboyi molochnoyi porody - Estimation of the exterior of the first-calf cows of the Sumy type of Ukrainian black-and-white dairy breed. Visnyk SNAU, Seriya «Tvarynnytstvo». - Visnyk of SNAU, Issue Livestock series. 10 (15):127-131 (in Ukrainian). 